Gál Marianna ${ }^{1}$

\title{
A katonai együttmüködés szervezetei a FÁK koordinációs rendszerében
}

\section{The Military Cooperation Bodies in the Coordination System of the CIS}

\begin{abstract}
Absztrakt
A FÁK-tagállamok közötti koordináció területei közül már 1999-töl, de sokkal inkább 2001-töl kiemelkedő jelentőségüvé vált a biztonságpolitikai együttmüködés szférájának mélyítése, amely napjainkban a terrorizmus és a kábitószer-kereskedelem ellen, valamint az illegális migráció visszaszorítására fókuszál a Védelmi Miniszterek Tanácsa és a Határörizeti Hatóságok Parancsnokainak Tanácsa védnöksége alatt. Jelen tanulmányomban e két intézmény Független Államok Közösségének koordinációs rendszerében betöltött szerepét vizsgálom.
\end{abstract}

Kulcsszavak: FÁK, katonai együttmüködés, intézményi rendszer, Védelmi Miniszterek Tanácsa, békefenntartó erők, határőrizeti együttmüködés

\begin{abstract}
From 1999, but much more from 2001, the deepening of the sphere of security policy cooperation, which focuses on counter-terrorism and drug trafficking and on the fight against illegal migration, has become salient in the areas of coordination between the CIS member states under the patronage of the Commanders of the Border Guard Authorities. In this study, I scrutinise the role of these two institutions in the Coordination System of the Commonwealth of Independent States.
\end{abstract}

Keywords: CIS, military cooperation, institutional system, Council of Ministers of Defense, peacekeeping forces, border surveillance cooperation

Debreceni Egyetem, doktorandusz - University of Debrecen, PhD student, e-mail: maryanna91@gmail.com, ORCID: https://orcid.org/0000-0003-2100-2729 


\section{Bevezetés}

A Független Államok Közössége (a továbbiakban: FÁK, Közösség) intézményesítésének szándéka első ízben a belavezsai alapítói okiratban fogalmazódott meg, amikor a szerződő felek leszögezték, a Közösség céljai elérését koordinációs testületeken keresztül kívánja elérni a „szuverén államok egyenlőségének elve” alapján. Ilyen testületekröl rövidesen döntés is született, hiszen már december végén megalapították a két legfontosabb tanácsot: az Államfők Tanácsát és Kormányfők Tanácsát. Az akkori szerződési tartalmak elfogadása óta azonban nyolc év telt el a FÁK-szervezetek végleges felépítéséről és reformjáról szóló szerződés hatályba lépéséig, amelynek során nemcsak praktikusan átformálódott az intézményi rendszer számos eleme, de több mint 70-re nőtt azon állam- és kormányközi intézményeknek száma, amelyek a Közösség hatékonyságának javítása érdekében a részt vevő tagállamok tevékenységének koordinálásával foglalkoznak, miközben a tagállamok száma is háromról 12-re, népessége pedig 209 millióról több mint 280 millióra növekedett. ${ }^{2}$ Noha a kilenc fő intézmény - Államfők Tanácsa, Kormányfők Tanácsa, Külügyminiszterek Tanácsa, Koordináció-tanácsadó Bizottság, Védelmi Miniszterek Tanácsa, Határőrizeti Hatóságok Parancsnokainak Tanácsa, Gazdasági Bíróság, Emberi Jogi Bizottság, ágazati együttműködés szervei - létrejöttét kifejezetten az 1993 januárjában elfogadott Alapokmány VI. fejezetében ${ }^{3}$ rögzítették, ezek közül az 1999. április 2-ai államfői döntés egy szervet, a Koordináció-tanácsadó Bizottságot először átszervezte a FÁK Végrehajtó Bizottságába, majd megszüntette azt. Megalakult továbbá egy új fórum: a Gazdasági Tanács (lásd: 1. ábra).

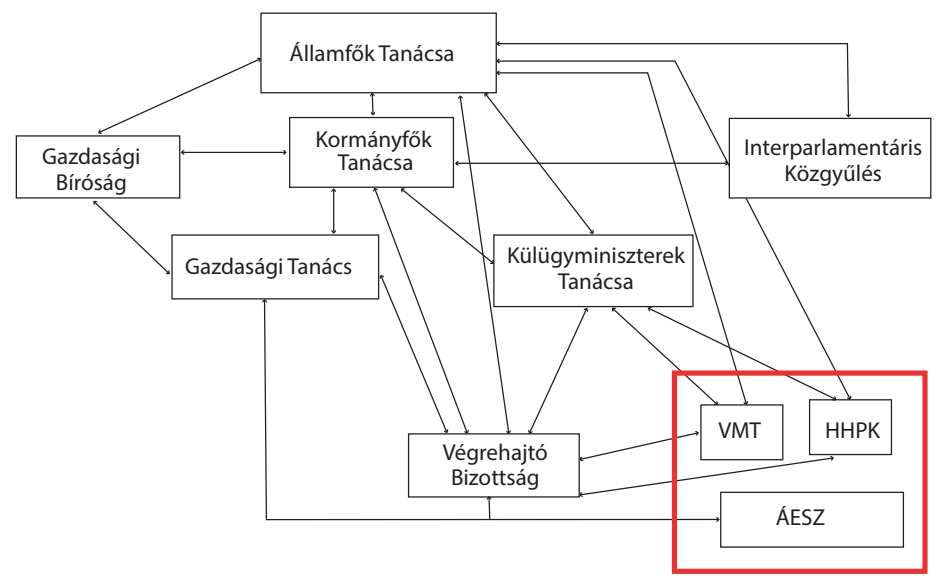

1. ábra: A FÁK intézményi rendszere

Forrás: a szerző szerkesztése

\footnotetext{
Решение о совершенствовании и реформировании структуры органов Содружества Независимых Государств. (Москва, 2 апреля 1999 года), https://zakon.rada.gov.ua/laws/show/997_412 (Letöltve: 2018. 10. 13.)

3 Статут Співдружності Незалежних Держав, http://zakon.rada.gov.ua/laws/show/997_033 (Letöltve: 2018. 10. 12.)
} 
A FÁK-tagállamok közötti koordináció területei közül már 1999-től, de sokkal inkább 2001-től kiemelkedő jelentőségúvé vált a biztonságpolitikai együttműködés szférájának mélyítése. A biztonsággal kapcsolatos testületek mindegyike orosz kezdeményezésre jött létre, és orosz dominanciával is müködik. Egyrészt magyarázatul szolgál erre vonatkozóan az a tény, hogy Oroszország rendelkezik a legnagyobb haderővel, amelyet a szervezet több területén is állomásoztat, másrészt, mert az erőteljes orosz befolyás érvényesülése biztosítja, hogy a szervezet az orosz biztonságpolitikai célokkal összhangban folytassa tevékenységét. Ez a megállapítás vonatkozik a Közösség legföbb védelmi intézményére, a Védelmi Miniszterek Tanácsára, ${ }^{4}$ de a mellette funkcionáló katonai-technikai bizottságra, amely a FÁK ideiglenesen létrehozott szervezete,

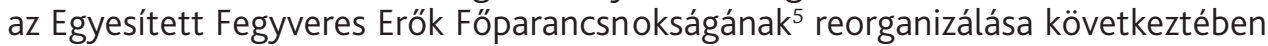
alakult. Jelenleg a Közösség biztonságpolitikai koo perációja a terrorizmus és a kábítószer-kereskedelem elleni harcra, valamint az illegális migráció visszaszorítására fókuszál.

\section{A Védelmi Miniszterek Tanácsa}

A FÁK felépítésének rendszerében az egyik legfontosabb szerepet az 1992 telén létrehozott Védelmi Miniszterek Tanácsa (a továbbiakban: VMT) tölti be, amely nemcsak koordinálja és összehangolja a közösség államainak a fegyveres konfliktusok megelőzésére irányuló erőfeszítéseit, de a tagállamok katonapolitikájának és katonai szervezeteinek kialakítására vonatkozó javaslatokat tesz az Államfők Tanácsának. Ebben az értelemben a koordinációs jogszabályok kidolgozásának feladata az Interparlamentáris Közgyüléstől a Védelmi Miniszterek Tanácsa felé tolódik át, lehetővé téve, hogy közvetlenül az Államfök Tanácsának védnöksége alatt egységes politika alakuljon ki az egész Közösség védelmi stratégiájának kialakítása terén.

Összetételét tekintve a Védelmi Miniszterek Tanácsát - annak alapokmányával összhangban - a tagállamok védelmi miniszterei közül választott elnök, az elnökhelyettesek és a tanács további, egyenlő jogokkal rendelkező tagjai alkotják. A döntéshozatalok során az érvényes elv: egy állam - egy szavazat.

A VMT tevékenységeinek biztosítására és a FÁK megfelelő szervezeti testületeivel való együttmüködése érdekében $17^{6}$ ideiglenes, és 2 állandó munkaügyi testületet hoztak létre: a tagállamok katonai együttmüködésének koordinációs bizottságát - a Tagállamok katonai együttmüködésének koordinációért felelös Parancsnokságát ${ }^{7}$-, valamint a Védelmi Miniszterek Tanácsának Titkárságát. Ugyanakkor a koordinációs bizottság funkcióit 2005. augusztus 26-ai rendelet alapján szüneteltették, majd a Titkárság hatásköre alá vonták 2006 januárjától a következő főbb feladatok ellátása érdekében:

4 Положение о Совете министров обороны государств-участников Содружества Независимых Государств, http:// mil.ru/smosng/about/documents/more.htm?id=12087397@egNPA (Letöltve: 2019. 01. 10.)

5 Соглашение об организации деятельности Главного командования Объединенных Вооруженных Сил Содружества Независимых Государств на переходный период, https://zakon.rada.gov.ua/laws/show/997_349 (Letöltve: 2018. 11. 12.)

6 Координационные комитеты СМО СНГ, http://mil.ru/smosng/units/coordinationcommittees.htm (Letöltve: 2018. 11. 13.)

Решение о Штабе по координации военного сотрудничества государств-участников Содружества Независимых Государств, https://zakon.rada.gov.ua/laws/show/997_209 (Letöltve: 2018. 12. 12.) 
- a FÁK-tagállamok közötti átfogó katonai együttmüködés fejlesztésének előmozdítása;

- a VMT, az Állam- és Kormányfők Tanácsa döntései végrehajtásának összehangolása a többoldalú katonai együttmüködés területén;

- a FÁK-tagállamok Védelmi Minisztereinek Tanácsa tevékenységének biztosítása:

- szervező-technikai, például részvétel a nemzetközösségi államok azon erőfeszítéseinek összehangolásában, hogy megfeleljenek a bizalomépítő intézkedésekről szóló nemzetközi megállapodásoknak és növeljék a katonai szféra nyitottságát, csökkentve a hagyományos fegyveres erőket és fegyvereket;

- információgyüjtö, -elemző, például a haderő kialakításával kapcsolatos elemző munkák, beleértve a világ katonai-politikai helyzetéről és a közösség országainak érdeklődési területeiről nyílt információ gyüjtése, összeállítása és elemzése;

- tanácsadó, például a FÁK-államok katonai kutatóintézetei tudományos eredményeinek tanulmányozása, elemzése és szintetizálása, a katonai kutatás, a haditechnikai fejlesztés irányaira vonatkozó politika, a haderők logisztikai támogatása, valamint a békefenntartó erők együttmüködésére irányuló javaslatok kidolgozása.

A Védelmi Miniszterek Tanácsa tevékenységének fő formája a rendszerint háromhavonta megtartott ülések, emellett kétharmados többségi támogatással a Tanács bármely tagja, az Államfők-, illetve a Védelmi Miniszterek Tanácsa elnökének javaslata alapján igényelhető rendkívüli ülés összehívása. Ezen megfigyelőként részt vehetnek azok a védelmi miniszterek vagy a közösség tagállamainak képviselői, amelyek vezetői nem írták alá a Védelmi Miniszterek Tanácsának határozatát. A Védelmi Miniszterek Tanácsa határozatával az üléseit a FÁK bármely más tagállamának területén is meg lehet tartani. Ebben az esetben a Védelmi Miniszterek Tanácsa ülésének előkészitésére és megszervezésére vonatkozó anyagi és technikai támogatást annak az államnak a honvédelmi minisztériuma biztosítja, amelynek területén ezen üléseket tartják.

\section{Katonai megfigyelőcsoportok és kollektív békefenntartó erők}

A közös fellépés lehetőségének fontos eleme a békefenntartó missziók létesítésére való képesség. A konfliktusok mértéke és súlyossága Tádzsikisztánban, Grúziában, Moldovában, Hegyi-Karabahban határozták meg a FÁK békefenntartási folyamatainak fő irányát, noha egyes adatok szerint a volt Szovjetunió területén 180 regionális konfliktus megoldatlan maradt, a FÁK létrehozása óta több mint 150 konfliktus a nemzetiségi alapon bontakozott ki, amelyek közül 20-at fegyveres összecsapások kísértek. ${ }^{8}$

Az 1992. március 20-án Kijevben a FÁK-államok Katonai megfigyelöiröl és a Kollektív erök békefenntartó tevekénységéröl ${ }^{9}$ megkötött szerződés hatása meglehetősen bizony-

Самсонов В. Основы формирования системы коллективной безопасности государств-участников СНГ, 1996, 15. Угода про Групи військових спостерігачів і Колективні сили з підтримання миру в Співдружності Незалежних Держав, https://zakon.rada.gov.ua/laws/show/997_1090 (Letöltve: 2018. 12. 10.) 
talan, annak ellenére, hogy valamennyi tagállam képviselője - nevezetesen Oroszország, Fehéroroszország, Örményország, Belarusz, Moldova, Kazahsztán, Üzbegisztán, Kirgizisztán és Tádzsikisztán - jóváhagyta, Azerbajdzsán kiegészítésekkel, Ukrajna pedig azzal a módosítással, miszerint valamennyi műveletben a Legfelsőbb Tanács határozatai alapján vesznek részt. A biztonságpolitikai együttmüködés intézményi keretéhez tartozó ideiglenes koalíciós csoport összetételét az e megállapodásban részes államok alkotják, a konfliktusban részt vevő feleket kivéve, amely egy békefenntartó művelet idejére annak érdekében jön létre, hogy segítse valamennyi FÁK-tagállam területén felmerülő konfliktus rendezését. Természetesen a békefenntartó műveletek nem helyettesítik a tárgyalásokon keresztül történő konfliktus rendezését, amelyek mindig prioritásban vannak az erő felhasználásával szemben, és nem sérthetik azon államok határainak szuverenitását, területi integritását, ahol tevékenységük végrehajtása történik. A békefenntartó erőket alkalmazó művelet lefolytatására irányuló politikai döntést az Államfök Tanácsa egyhangúlag hagyja jóvá a Külügyminiszterek Tanácsa és a Védelmi Miniszterek Tanácsa ajánlása alapján.

A konfliktusmegoldási mechanizmusok a „Koncepciók a Független Államok Közössége államai területén a konfliktusok megelőzésére és megoldására"10 elnevezésü, 1996. január 19-én elfogadott dokumentum alapján történnek, ami a keletkezett feszültség szintjéből kiindulva három szakaszra osztható: konfliktusmegelözés, fegyveres konfliktus rendezése, konfliktus utáni béketeremtés. Az okmány IV. szakasza szabályozza a Kollektív Békefenntartó Erők (a továbbiakban: KBE) alkalmazási alapját a FÁK-ban: a konfliktusterületre csak az egymással szemben álló felek közötti tűzszüneti vagy fegyverszüneti megállapodás megkötése és ezeknek a megállapodásoknak a végrehajtása után tudják bevezetni, tehát az első és második szakasz szoros összefüggésben áll egymással. Ennek megfelelően a békefenntartó erők tevékenysége a második szakaszban válik hangsúlyossá, ugyanis a konfliktusmegoldás ezen fázisa tartalmazza azt a sor eszközt, amelyek a művelet végrehajtása során a KBE feladatai közé tartoznak:

- a fegyverszüneti és a tűzszüneti megállapodás feltételei betartásának ellenörzése, hozzájárulás a biztonságos környezet megteremtéséhez a problémás területeken a KBE jelenlétének biztosításával;

- felelösségi körök kijelölése, a szembenálló felek elkülönítése, demilitarizált zónák, elkülönítő övezetek, humanitárius folyosók létrehozása, az erőfelek dekoncentrálódásának elősegítése, mozgásaik és összeütközésük megelőzése ezeken a területeken;

- megfelelő körülmények megteremtése tárgyalások és egyéb rendezvények részére a konfliktus békés megoldásának érdekében;

- a jog és a rend helyreállítása, állami intézmények és szervezetek rendeltetésszerü müködése;

- a tủzszüneti megállapodások és a fegyverszünet megsértésének megállapítása és kivizsgálásának lefolytatása;

10 Решение о Концепции предотвращения и урегулирования конфликтов на территории государств-участников Содружества Независимых Государств, (Москва, 19 января 1996 г.), https://online.zakon.kz/Document/?doc id=1011449\# pos=1;-80 (Letöltve: 2018. 12. 14.) 
- a lakosság helyzetének és intézkedéseinek ellenőrzése a felelősségvállalt területén, a tömeges zavargások elleni küzdelem, az emberi jogok biztosításának előmozdítása;

- az erődítmények, torlaszok és aknamezők leszerelésének ellenőrzése;

- a létfontosságú létesítmények védelme;

- intézkedések az egymással szemben álló felek közötti kommunikáció és a köztük lévő hivatalos találkozók biztonsága érdekében minden szinten;

- a szállítás ellenőrzése, a katonai felszerelések, fegyverek, löszerek és robbanóanyagok jogellenes behozatalának és exportjának visszaszorítása;

- a biztonságos tranzit biztosítása minden közlekedési típusnál és a kommunikáció működtetése;

- normális kapcsolatok elősegítése a szembenálló felek lakosai között;

- a civilek számára nyújtott humanitárius segítségnyújtás megkönnyítése;

- a humanitárius segítségnyújtás akadálytalan ellátásának biztosítása;

- részvétel az ENSZ Biztonsági Tanácsának, az EBESZ szervezeteinek és más nemzetközi szervezeteknek a konfliktus békés rendezésére vonatkozó döntéseinek és ajánlásainak végrehajtásában.

A katonai megfigyelők csoportját a konfliktusmegoldási mechanizmus harmadik szakaszában arra alkalmazzák, hogy figyelemmel kísérjék és ellenőrizzék, hogy a konfliktusban részt vevő felek hogyan tesznek eleget kötelezettségvállalásaiknak: például tűzszüneti megállapodásoknak, korlátozzák-e a fegyveres erők számát egy adott területen, esetleg visszavonják-e csapataikat. A katonai megfigyelők tevékenysége lényegében arra irányul, hogy meggyőzzék a feleket kötelezettségeik tiszteletben tartásáról, tủzszüneti megállapodás megsértése esetén pedig helyreállítsák a status quo-t. A szakértői csoport célja, hogy tanulmányozza és értékelje a katonai-politikai helyzetet, az elszámolási folyamatokat, a KBE intézkedéseit, elöre jelezze a helyzet alakulását, és megalapozott javaslatokat készítsen elő a parancsnok döntéshozatalára vonatkozóan.

\section{A határörizeti hatóságok parancsnokainak tanácsa ${ }^{11}$}

A biztonságpolitikai együttműködés kiemelkedően fontos dimenziója a határőrizeti szervek munkájának összehangolása, az az integrációs szint, amelynél a szupranacionális központosítási igény már felülmúlja a tagállamok által kívánt mértéket. A határszervek saját hatáskörben tartása a FÁK-államok biztonsági szemszögéböl nélkülözhetetlen, különös tekintettel függetlenségük kezdeti szakaszán, amikor a szovjet tagköztársaságokat egymástól elválasztó adminisztrációs határokat a felbomlás nyomán nemzetközi státusz váltotta fel.

11 Решение о создании Совета командующих Пограничными войсками, http://cis.minsk.by/reestr/ru/index.html\#reestr/ view/text?doc=131 (Letöltve: 2018. 12. 13.) 
A mai európai országok közjogi határai többnyire jól definiáltak, ami azt jelenti, hogy ezeket a határokat nemzeti és nemzetközi jogi nyilatkozatokban deklarálták, amelyeket nemzetközi közösségek, szervezetek legitimnek tekintenek. Ezzel szemben a posztszovjet államok határai, különös tekintettel az orosz-ukrán határra, kevésbé egyértelmüek, és messze nem övezi azokat az említetthez hasonló konszenzus. A határértelmezésekben orosz részröl gyakran jelen van területi expanzió érvényesítésének, a Szovjetunió valamiféle restaurációjának szándéka. Bizonyítékként szolgálhat erre vonatkozóan az a tény, hogy a posztszovjet térség külső határainak nagy része nem volt delimitált, vagyis azokat nem a határ két oldalán lévő politikai közösségek legitim képviselői jelölték ki és foglalták szerződésbe, hanem a mindenkori moszkvai vezetés politikai akarata. Ebből a szempontból, nem meglepő módon, a határvédelem megszervezése sem bizonyult egyszerű feladatnak.

A szovjet korszak egyik utolsó jogszabályának megfelelően a határőrzés megszervezését a szuverén köztársaságok államhatárai és gazdasági érdekvédelme terén az SZSZKSZ Határőrizeti Bizottsága ${ }^{12}$ látta el az átmeneti - 1991 decemberétől 1992 márciusáig terjedő - időszakban. Érdemes megjegyezni, hogy a koordinációs eszközök, amik a Közösség elsődleges fejlődési szakaszában jöttek létre, gyakorlatilag teljes egészében megengedték a nemzeti határőrség potenciáljának megmaradását, valamint biztosították a közösség országainak stabilitását az átmeneti időszakban.

A korszak fő jellemzője ugyanakkor, hogy egyes országok - részben az Azerbajdzsán Köztársaság, a Moldva Köztársaság és Ukrajna - független határbiztonsági politikát folytattak, megszervezve saját határőrségüket, ami számos problémát vetett fel a határozathozatal központosítása során.

A FÁK-országok államfői a határőrség főparancsnokaival közösen szorgalmazták a határörség tevékenységére vonatkozó mechanizmus kidolgozását, különös tekintettel a FÁK-országok nemzeti jogszabályainak követelményeire, azon országok kivételével, amelyekben már ki volt dolgozva egy hasonló rendszer. 1992. március 20-án a Közösség államfői kijevi találkozójukon határozatot hoztak a határőrség parancsnokságának egységesítéséröl. ${ }^{13} \mathrm{Az}$ ülés folyamán megállapodás-csomagot írtak alá a FÁK-országok államhatárainak védelmével kapcsolatos kérdésekben és a FÁK határőrségének státuszára vonatkozóan. A határőrség parancsnokságának egységesítéséről szóló határozat elfogadásával az SZSZKSZ Határőrizeti Bizottság tevékenysége az SZSZKSZ államhatárainak védelmére vonatkozóan megszünt.

A FÁK-országok Államfői Tanácsa 1992. július 6-án határozatot hozott az egységes határőr-parancsnokság megszüntetéséröl és egyúttal a Határőrizeti Hatóságok Parancsnokainak Tanácsa ${ }^{14}$ (a továbbiakban: HHPT, Parancsnokság) létrehozásáról, amely a FÁK-országok Államföi Tanácsának teljes hatáskörével rendelkezik a tagállamok határőrzési kérdéseire, illetve határőrzési politikájának egységessé tételére

12 Указ Президента Союза Советских Социалистических Республик Об Утверждении Временного Положения О Комитете По Охране Государственной Границы СССР, www.libussr.ru/doc_ussr/usr_19772.htm (Letöltve: 2018. 12. 14.)

13 Соглашение об Объединенных Вооруженных Силах на переходный период, http://cis.minsk.by/reestr/ru/index. html\#reestr/view/text?doc=59 (Letöltve: 2018. 12. 15.)

14 Решение о создании Совета Командующих Пограничными Войсками, http://cis.minsk.by/reestr/ru/index. html\#reestr/view/text?doc=131 (Letöltve: 2018. 12. 15.) 
vonatkozóan a Közösség határain. Feladata, hogy kidolgozza és megvizsgálja a belső határok és gazdasági övezetek védelmére irányuló koncepciókat, figyelembe véve a FÁK-országok érdekeinek védelmét, javaslatokat és projekteket készít elő a FÁKtagországok határvédelmi tevékenységének koordinációjára vonatkozóan, és olyan kérdésekben, amelyek közös fellépést követelnek. A Parancsnokság tevékenységének céljai között szerepel:

- az Állam- és Kormányfök Tanácsa által hozott döntések végrehajtásának megkönnyítése, valamint a határvédelmi kérdésekre vonatkozó FÁK-alapokmány rendelkezéseinek végrehajtása;

- a határőrizeti csapatok erőfeszítéseinek összehangolása a külső határok és gazdasági övezetek védelme terén, valamint stabil helyzetük biztosítása;

- a tagállamok határőrségei közötti baráti kapcsolatok fejlesztése;

- segítségnyújtás a FÁK-országok határörségének fejlesztésében és megerősítésében a határkérdésekre és azok védelmére vonatkozó nemzeti jogszabályok közelítése, kölcsönös információcsere, együttmüködés a katonai-technikai politika és a személyzetképzés területén.

A Határőrizeti Tanács feladatainak teljes értékű végrehajtására vonatkozóan 1992. október 9-én egy állandóan működő munkaügyi testületet is létrehoztak, a Koordinációs Szolgálatot, amelyet napjainkban Alekszandr Malyinov vezérezredes irányít. ${ }^{15}$ Ezenkívül még további ideiglenes munkabizottságok szolgálják a HHPT munkáját:

- Munkabizottság a bűnmegelőzés, a kábítószer- és tudatmódosítószer-kereskedelem, a terrorizmus és egyéb erőszakos szélsőségek, törvénytelen migráció elleni harcra.

- Koordinációs tudományos tanács.

- Tanács a FÁK-országok határőrizeti hivatalai közötti együttmüködésre - a kultúrára és a veteránokra vonatkozóan.

- FÁK-országok határőrizeti hivatalai sporttanácsa-a FÁK-országok belső határhelyzetének monitoringjára és elemzésére vonatkozó csoport.

A Parancsnokság tagjai azon $11^{16}$ FÁK-ország határőrségi egységeinek parancsnokai, akik aláírták a Határőrizeti Hatóságok Parancsnokainak Tanácsa létrejöttéről szóló Államfők Tanácsa által hozott határozatot, továbbá a Koordinációs Szolgálat képviselője szavazati joggal.

A Határőrizeti Tanács negyedévente egy alkalommal a Közösség tagállamainak fövárosában ülésezik. Rendkívüli üléseit az Állam- vagy Kormányfők Tanácsának kérésére, valamint a HHPT egy vagy több tagjának igénylése esetén, legalább kétharmados többség beleegyezése esetén hívják össze.

A FÁK-országok határellenőrzési együttmüködése az elmúlt években produktív módon fejlődött. Hozzájárult a nemzeti határőrségek kialakulásához, a határmenti együttműködés jogi területének létrehozásához. Az illegális migráció, a terroristacsoportok

15 Координационная служба - постоянно действующий рабочий орган Совета командующих Пограничными войсками, www.skpw.ru/sections/ksskpw/historyksskpw.html (Letöltve: 2018. 12. 18.)

16 Örményország, Belarusz, Kazahsztán, Kirgizisztán, Tádzsikisztán Moldova, Oroszország. 
beszivárgása, a kábítószer-kereskedelem, a fegyverek, lőszerek és robbanóanyagok, a nyersanyagok és a kulturális értékek csempészete szükségessé teszi a határmenti együttmúködés fejlesztését a Közösség „belső” határain. Ugyanakkor ez nemcsak kétoldalú alapon építhető, számos probléma közös erőfeszítéseket igényel a FÁK-on belül.

A közös tanács távlati célja az integráció mélyítése, amelyben Moszkva egyelöre csak Kazahsztánra, Fehéroroszországra, Kirgizisztánra, Tádzsikisztánra és Örményországra számíthat. Ezt bizonyítja az 1995 májusában elfogadott, a közösségi államokkal folytatott határbiztonsági együttműködésről szóló koncepció és az államtitkárság 1995 májusában elfogadott megállapodása, amely nemcsak az átfogó és egyenlő partnerség e fontos területen történő megrendelését határozta meg, hanem a kollektív döntések elsőbbségét, a FÁK külső határai megbízható védelmének kölcsönös felelősségét. Sajnos csak hét állam írta alá a koncepciót és a szerződést, illetve további négy ratifikálta azt, bár mind a 12 államnak közös határai vannak harmadik országgal. Most gyakorlatilag öt-hat állam vesz részt a koncepció és a szerződés rendelkezéseinek végrehajtásában, amíg a többi az alapvető dokumentumok aláírására hivatkozik, amelyek a FÁK „külső" határainak védelmére irányuló együttműködésre utalnak.

\section{Felhasznált irodalom}

Самсонов В. Н.: Основы формирования системы коллективной безопасности государств-участников СНГ, М., 1996.

Угода про Групи військових спостерігачів і Колективні сили з підтримання миру в СНД, https://zakon.rada.gov.ua/laws/show/997_1090 (Letöltve: 2018. 12. 10.)

Координационная служба - постоянно действующий рабочий орган Совета командующих Пограничными войсками, www.skpw.ru/sections/ksskpw/historyksskpw.html (Letöltve: 2018. 12. 18.)

Координационные комитеты СМО СНГ, http://mil.ru/smosng/units/coordinationcommittees.htm (Letöltve: 2018. 11. 13.)

Положение о Совете министров обороны государств-участников СНГ, http:// mil.ru/smosng/about/documents/more.htm?id=12087397@egNPA (Letöltve: 2019. 01. 10.)

Решение о создании Совета Командующих Пограничными Войсками, http://cis. minsk.by/reestr/ru/index.html\#reestr/view/text?doc=131 (Letöltve: 2018. 12. 15.)

Решение о Штабе по координации военного сотрудничества государствучастников СНГ., https://zakon.rada.gov.ua/laws/show/997_209 (Letöltve: 2018. 12. 12.)

Решение о Концепции предотвращения и урегулирования конфликтов на территории государств-участников СНГ, (Москва, 19 января 1996 г.) https:// online.zakon.kz/Document/?doc_id=1011449\#pos=1;-80 (Letöltve: 2018. 12. 14.)

Решение о создании Совета командующих Пограничными войсками, http://cis. minsk.by/reestr/ru/index.html\#reestr/view/text?doc=131 (Letöltve: 2018. 12. 13.)

Соглашение об Объединенных Вооруженных Силах на переходный период, http://cis.minsk.by/reestr/ru/index.html\#reestr/view/text?doc=59 (Letöltve: 2018. 12. 15.) 
Соглашение об организации деятельности Главного командования Объединенных Вооруженных Сил Содружества Независимых Государств на переходный период, https://zakon.rada.gov.ua/laws/show/997_349 (Letöltve: 2018. 11. 12.) Указ Президента Союза Советских Социалистических Республик Об Утверждении Временного Положения О Комитете По Охране Государственной Границы CCCP, www.libussr.ru/doc_ussr/usr_19772.htm (Letöltve: 2018. 12. 04.) 